\title{
ADMINISTRATIVE ADJUDICATION IN THE PROCESS OF THE ASSOCIATION REGISTRATION IN THE REPUBLIC OF CROATIA
}

\author{
Dario Đerda, PhD, Full Professor \\ University of Rijeka, Faculty of law, Chair of administrative law \\ Hahlić 6, HR-51000 Rijeka \\ dario.derda@pravri.hr
}

\author{
Marina Dereta, univ. spec. iur. (Univ. Spec. in Med. Law) \\ Primorje-Gorski Kotar County \\ Adamićeva 10, HR-51000 Rijeka \\ marina.maljkovic@gmail.com
}

\begin{abstract}
This paper aims to analyze the legal regulation of association registration in the Republic of Croatia and to determine whether the provisions on association registration in the Registry Book of Associations and the acquisition of legal personality of associations have achieved proportionality in the protection of parties' rights and protection of the public interest. For this purpose, the concept and role of associations in the Republic of Croatia is first considered. Next, the process of establishing and registering associations in the Registry Book of Associations, as a constitutive element of an association acquiring legal personality, is analyzed. Particular attention is thereby paid to the statutory presumption of registration when the competent authority does not issue a decision rejecting the request for association registration within the prescribed period. It probes the justification of such a normative approach and compares it with the legal solutions present in German, French, Italian, Slovenian, and Serbian law. Finally, in conclusion, the authors evaluate the quality of Croatia's approach to the association registration into the Registry Book of Associations.
\end{abstract}

Keywords: association, registration, administrative procedure, statutory presumption of registration, Croatia 


\section{INTRODUCTION}

The right to freedom of association is one of the fundamental human rights guaranteed by regulations at the international and national level. It provides the foundation for accomplishing a number of goals and tasks of interest to the daily lives of individuals. Recently, states have comprised within their jurisdictions only those activities related to the direct exercise of public authority while a number of activities of importance to individuals, such as the provision of utilities, health and education services, care for children, the elderly and infirm, etc., tasked institutions and companies that perform them as public services. ${ }^{1}$ The pursuit of citizens' other interests, which national, regional, or local regulations do not define as being of public interest, is left to the citizens themselves and, as a rule, they engage in them by establishing different formal and informal organizational structures. Moreover, today, through the many structures of civil society unity, efforts are made to respond to the increasingly complex and demanding needs of everyday life.

Associations are a very common organizational form of achieving the non-political goals of individuals. An association is considered to be any form of free and voluntary association of several natural or legal persons for the purpose of protecting their interests or standing up for certain values without the intention of obtaining profit or other economically estimable benefits. Their activities promote the protection of human rights and freedoms, environmental protection and sustainable development, humanitarian, social, cultural, educational, scientific, sports, health care, technical, information, professional or other beliefs and goals of individuals. ${ }^{2}$ Thus, associations represent one of the fundamental forms of realization of the right to freedom of association and are considered an important segment of civil society and the non-profit sector. Precisely its volunteerism, non-profit nature, independence, and the pursuit of the general interest are the distinctive characteristics of this organizational form founded with the aim of involving its members in public life. Through this platform, members of associations are free to participate in the development, monitoring, implementation, and evaluation of public policies, in shaping public opinion, expressing their views and opinions, and taking initiatives to achieve their goals. ${ }^{3}$

1 See more on the public services in Blažević, R., Upravna znanost, Faculty of Law, University of Rijeka, Rijeka, 2007, pp. 217 - 218. See more on the development of the public services in Koprić, I., Razvoj i problemi agencijskog modela s posebnim osvrtom na nezavisne regulatore, in: Koprić, I.; Musa, A.; Đulabić, V. (eds.), Agencije u Hrvatskoj: Regulacija i privatizacija javnih službi na državnoj, lokalnoj i regionalnoj razini, Institute for Public Administration, Zagreb, 2013, pp. 2-3

2 See Article 4 of the Law on Associations, Official Gazette, no. 74/2014, 70/2017, and 98/2019

3 See Article 10 of the Law on Associations 
The importance of freedom of association in Europe has been recognized as a particular value that Member States should strive for. With its European Convention for the Protection of Human Rights and Fundamental Freedoms, the European Council has recognized the right of every person to freedom of association with others, including the right to form or join trade unions for the protection of their interests. ${ }^{4}$ The European Union has done the same, establishing with the Charter of Fundamental Rights of the European Union the right of every individual to freedom of association at any level, especially when it comes to political, trade union, and civil matters, which also implies the right of everyone to form and join these organizations in order to protect their interests. ${ }^{5}$

In the Republic of Croatia, freedom of association has been established by the Constitution as one of the fundamental rights of its citizens. Each person is guaranteed free association for the protection of interests or the pursuit of social, economic, political, national, cultural, or other beliefs and goals and, for this purpose, everyone is entitled to form, join, or withdraw from trade unions and other associations in accordance with the law. ${ }^{6}$ Freedom of association is elaborated in more detail in the Law on Associations, which regulates the establishment, legal status, operation, registration, financing, property, liability, status changes, supervision, termination of the existence of an association with legal personality, and registration and termination of activity of foreign associations in the Republic of Croatia, unless a special law stipulates otherwise. ${ }^{7}$

Despite its importance, the right to freedom of association is not, however, an absolute right and may be restricted in certain circumstances. The European Convention for the Protection of Human Rights and Fundamental Freedoms legally prohibits the restriction of this freedom unless such restriction in a democratic society is necessary for the interests of national security or public order and peace, for the prevention of disorder or crime, for the protection of health or morals, or for the protection of rights and freedoms of others. ${ }^{8}$ The Charter of Fundamental Rights of the European Union sets out the general reasons for restricting the rights

Article 11, paragraph 1 of the European Convention for the Protection of Human Rights and Fundamental Freedoms, Official Gazette - International agreements, no. 18/1997, 6/1999, 14/2002, $13 / 2003,9 / 2005,1 / 2006$, and 2/2010

5 Article 12, paragraph 1 of the EU Charter of Fundamental Rights, (2016) OJ C 202/389-405

6 Article 43, paragraph 1 of the Constitution of the Republic of Croatia, Official Gazette, no. 56/1990, 135/1997, 8/1998, 113/2000, 124/2000, 28/2001, 41/2001, 55/2001, 76/2010, 85/2010, and $05 / 2014$

7 Law on Associations, Official Gazette, no. 74/2014, 70/2017, and 98/2019

8 Article 11, paragraph 2 of the European Convention for the Protection of Human Rights and Fundamental Freedoms 
guaranteed therein, which then apply to freedom of association. Any restriction of the exercise of the rights and freedoms recognized by this Charter must always be prescribed by law and must respect the essence of those rights and freedoms. In accordance with the principle of proportionality, restrictions are only permissible if they are necessary and in accordance with the general interest objectives recognized by the Union or the need to protect the rights and freedoms of others. ${ }^{9}$ It is clear from supranational regulations binding in all EU Member States, including Croatia, that the right to freedom of association can be restricted only if the following three conditions have been cumulatively fulfilled: such a restriction must be prescribed by law, it must have a legitimate aim and, finally, it must be necessary in a democratic society. ${ }^{10}$

In the Republic of Croatia, the Constitution restricts the freedom of association. The Constitution stipulates that rights and freedoms in Croatia can be restricted only by law in order to protect the rights and freedoms of other people and the legal order, public morals, and health. It also provides that any restriction of rights and freedoms must be proportionate to the nature of the need for restriction in each individual case. In addition to this general provision on the restriction of rights and freedoms, the Croatian Constitution also stipulates specific restrictions relating exclusively to the freedom of association. Consequently, the right of free association in Croatia may be further restricted because of the threat of violent danger to the democratic constitutional order, independence, uniqueness, and territorial integrity of the Republic of Croatia. ${ }^{11}$ Thus, it may be concluded that freedom of association is, in principle, allowed, with particular restrictions which the public authority must take into consideration, so that the exercise of this freedom does not endanger the democratic constitutional order, independence, uniqueness, and territorial integrity of the Republic of Croatia. In doing so, it is important to emphasize that, in the view of the European Court of Human Rights, the reasons for limiting freedom of association to protect this right should be interpreted restrictively, and this freedom can only be restricted for compelling and justified reasons prescribed by law, whereby any restriction to the freedom of association must be proportionate to the legitimate goals that it should serve in a

9 Article 52, paragraphs 1, 3, and 4 of the EU Charter of Fundamental Rights (2016) OJ C 202/389405

10 Radin, M., Pravo na slobodu okupljanja i udruživanja u praksi Europskog suda za ljudska prava i Ustavnog suda Republike Hrvatske, Hrvatska pravna revija, vol. 10, n. 10, 2010, pp. 4-5

11 Article 16 and article 43, paragraph 2 of the Constitution of the Republic of Croatia. See also Trgovac, S., Pravo na slobodu udruživanja u praksi Ustavnog suda Republike Hrvatske, Hrvatska pravna revija, vol. 10., n. 6, 2010, pp. 8-9 
democratic society. ${ }^{12}$ Thus, the legal system of the Republic of Croatia faithfully reflects the restrictions on freedom of association laid down at the European level.

This paper aims to analyze the legal regulation of association registration in the Republic of Croatia and to determine whether the provisions on the association registration in the Registry Book of Associations and the acquisition of legal personality of associations have achieved proportionality in the protection of parties' rights and protection of public interest. For this purpose, the concept and role of associations in the Republic of Croatia is first considered. Next, the process of establishing and registering associations in the Registry Book of Associations, as a constitutive element of an association acquiring the legal personality, is analyzed. Particular attention is thereby paid to the statutory presumption of registration when the competent authority fails to make a decision within the prescribed period to reject the application for association registration. It probes the justification of such a normative approach and compares it with the legal solutions present in German, French, Italian, Slovenian, and Serbian law. Finally, in conclusion, the authors evaluate the quality of Croatia's approach to association registration into the Registry Book of Associations.

\section{THE CONCEPT AND ROLE OF ASSOCIATIONS IN THE CROATIAN LEGAL SYSTEM}

In the Republic of Croatia, an association is understood as any form of free and voluntary association of natural or legal persons who, in order to protect their interests or to promote the protection of human rights and freedoms, environmental protection and sustainable development, humanitarian, social, cultural, educational, scientific, sports, health care, technical, information, professional or other beliefs and goals that are not contrary to the Constitution and law, without the intention of making profit or other economically estimable benefit, submit themselves to the rules that regulate the organization and activities of this form of association. ${ }^{13}$

An important characteristic of an association is certainly its legal personality, which makes it an entity that can take legal actions and be the holder of rights and obligations. An association acquires legal personality on the day of its entry in the Registry Book of Associations of the Republic of Croatia. Thus, the registration of an association in the Registry Book is considered to be a constitutive moment of

\footnotetext{
12 See Judgment Sidiropoulos v Greece (1999) 27 EHRR 633, See also Kotlo, R., Pravo na udruživanje, političke partije i nevladine organizacije u savremenom pravno-političkom sistemu, uporednom i mecunarodnom pravu, University Press, Sarajevo, 2017, p. 50

13 Article 4 of the Law on Associations
} 
its establishment in connection with the possibility of acquiring rights and obligations. ${ }^{14}$ However, in accordance with the Law on Associations, any other form of free and voluntary association of several natural or legal persons is considered an association, even when such an association is not entered in the Registry Book of Associations of the Republic of Croatia. Therefore, in Croatia, associations should be distinguished depending on whether or not an association has legal personality. The association registration in the Registry Book of Associations of the Republic of Croatia creates a new legal entity that can fully operate and acquire rights and obligations in the legal system. If the association is not registered in the Registry Book of Associations, it has no legal personality. As such, it may operate within the Croatian legal system, but in accordance with the regulations applicable to partnerships, not associations. ${ }^{15}$

Therefore, in Croatian law, no distinction is drawn between associations depending on the activity they perform, but rather depending on whether the association has legal personality or not. This is also a matter of differentiation on the basis of which the relevant law applicable to a particular association is established. ${ }^{16}$ An association registered in the Registry Book of Associations may participate in legal transactions, acquire rights, and assume obligations, be the owner of property, and participate as an actively or passively legitimized party in proceedings before the courts and administrative bodies, and the members of such association are not liable for the assets of the association with their private assets. Associations without legal personality do not enjoy rights and benefits such as those registered in the Registry Book of Associations. For example, such associations cannot be financed by public funds, they do not enjoy some financial privileges, and the status of the members of these associations is different given their liability for the association's obligations. Members of an unregistered association are independently liable for the obligations of such an association. ${ }^{17}$

It is undisputed that the association registration in the Registry Book of Associations represents a significant advantage for the association as well as its members, in comparison with the legal regime of associations not registered in this Register. Therefore, it seems that particular attention should be paid to the legality of the

\footnotetext{
14 See Article 5 of the Law on Associations

15 Article 2, paragraph 3 of the Law on Associations. See also Article 637, paragraphs 1 and 2 of the Civil Obligations Act, Official Gazette, no. 35/2005, 41/2008, 125/2011, 78/2015, and 29/2018

16 See also Brnabić, R., Odgovornost za obveze udruga s pravnom osobnošću, Pravo u gospodarstvu, vol. 51, n. 6, 2012, p. 1515

17 Barbić, J., Pravo društava - knjiga druga, Društva kapitala, Organizator, Zagreb, 1999, p. 7, and Zlatović, D., Neformalne udruge prema Zakonu o udrugama i Zakonu o obveznim odnosima, Komore i udruge, Lexpera d.o.o.-Ius info, 2019, pp. 1 and 3
} 
founding of associations as soon as they are registered and have acquired legal personality, and that the work of those associations that are not founded in accordance with Croatian legislation or perform any activity contrary to constitutional values in the Republic of Croatia would not be allowed. ${ }^{18}$ This, of course, does not preclude the monitoring of the association's activities during its existence, which is focused on the activities undertaken by the association itself and its compliance with legal regulations.

\section{ASSOCIATION REGISTRATION IN THE REGISTRY BOOK OF ASSOCIATIONS}

As already emphasized, the fundamental distinction between associations in Croatia depends on whether or not an association is registered in the Registry Book of Associations and, consequently, if it has acquired legal personality or not. Whether the association will be registered in the Registry Book depends on the will of its founder. Registration is voluntary and is carried out at the request of the association's founder. The Registry Book of Associations and the Registry Book of Foreign Associations are central electronic databases kept with the competent administrative body, uniformly for all associations, i.e., foreign associations in the Republic of Croatia. The associations are registered in the Registry Book of Associations kept by the counties' offices, i.e., the City of Zagreb, according to the seat of the association. ${ }^{19}$

An association is founded by at least three founders. Any natural or legal person may become a member of the association, in accordance with the law and the statute of the association..$^{20}$ For the purpose of founding an association, it is necessary to hold a founding assembly. Minutes on the decisions of the founding assembly are recorded. Although there is no prescribed course how the founding assembly is held, it is common to determine the number of persons present at the beginning of the session and whether these persons are also its founders. The list of founders of the association shall be attached to the minute of the founding assembly and is considered its integral part. At the founding assembly, a decision is first made to establish the association, then the statute of the association is adopted, and the election of the association body is initiated. At the same time, the persons empowered to represent the association are named and its liquidator is appointed. Finally, a decision is made to initiate the process of registering the association in the Registry Book of Associations.

\footnotetext{
18 See Judgment Refah Partisi and others $v$ Turkey (2003) 37 EHRR 1

19 Article 22, paragraphs 1, 3, and 4 of the Law on Associations

20 Article 11, paragraph 1 and Article 12, paragraph 1 of the Law on Associations
} 
The application for entry in the Registry Book of Associations, on behalf of the founder, is submitted by the person empowered to represent the association. The application for registration shall be accompanied by a record of the activities and decisions of the founding assembly, the decision of the assembly to initiate the procedure for registration in the Registry Book of Associations, if such decision was not made at the founding assembly, two copies of the statute, the list of founders and persons empowered to represent the association, a copy of the identity cards or passports of the founders, liquidators, and persons empowered to represent the association, an extract from the court or another Registry Book for a foreign legal person of the founder of the association, and a copy of the identity card or passport of its representative in the association, the consent or approval of the competent authority to perform a specific activity, when prescribed by a special law as a condition for registration of an association, certified consent of a legal representative or guardian if the founder of the association is a minor who has reached the age of 14 or an adult deprived of legal capacity in the part of concluding legal transactions, if the name or part of the name of the person is entered into the name of the association, certified statement from that person, i.e., the consent of his successors, and the certified consent of the international organization, if the name or logo of the association is entered into its name. ${ }^{21}$

The registration of an association in the Registry Book of Associations is decided in the administrative procedure. If the official conducting the proceeding determines that the statute of the association is not in accordance with the law or if the application is not accompanied by the prescribed annexes, it shall notify the applicant by an act to that effect and shall invite the applicant for registration into the Registry Book to harmonize the statute, or submit evidence, within a period for compliance which cannot be shorter than 15 days. The authority decides on the application for registration in the Registry Book by a decision. The law stipulates that this decision should be made within 30 days from the day of submitting a duly filed application for registration. The decision on the registration in the Registry Book of Associations must include title, seat and date of the entry, the registry number of the entry, basic aims of association's activities, economic activities, if prescribed by the statute, statement that the association acquires its legal personality upon registration, and that the registration in the Registry Book of Associations shall be carried out on the date of enforcement of the decision, the name of the liquidator of the association and the names of the persons empowered to represent the association. The competent authority shall reject the application

21 Article 23 of the Law on Associations and Article 7 of the Regulation on the forms and manner of keeping the Registry book of associations and the Registry book of foreign associations in the Republic of Croatia, Official Gazette no. 4/2015 and 14/2020 
for entry in the Registry Book of Associations if the statutory goals and activities are prohibited in the Constitution or law, and when the applicant fails to act on the conclusion inviting the applicant to align the statute of the association with the law or fails to submit the legally prescribed documents within the deadline set by the competent authority, which may not be within less than 15 days.

It is important to note here that, when establishing an association, the competent authority pays particular attention to the goals and activities of the association, which must be clearly stated in its statutes. In this way, this body monitors whether the association will violate the legal order, public morals, and human health in the Republic of Croatia through its activities, and whether it violently endangers the democratic constitutional order and the independence, uniqueness, and territorial integrity of the Republic of Croatia. If it assesses the existence of such danger, the competent authority shall issue a decision which rejects the request for the association to be entered in the Registry Book of Associations. Such a decision may be appealed; however, it shall not delay the execution of the decision. The registration in the Registry Book of Associations is carried out after the enforcement of the decision on registration. ${ }^{22}$

Such legal regulation of the administrative adjudication is commonplace and is fully aligned with the provisions of the General Administrative Procedure Act. ${ }^{23}$ However, the provision of the Law on Associations, as a separate law, stipulates that in the case when the competent authority does not make a decision on registration in the Registry Book of Associations within 30 days from the submission of a duly filed application, it should be considered that the association is entered into the Registry Book of Associations on the first day following that deadline. ${ }^{24}$ In the case of failure to pass a decision on the registration in the Registry Book of Associations within the legally prescribed deadline, in Croatia, the positive, i.e., affirmative statutory presumption of registration has been adopted in case of the silence of the administrative body. Such a case in the Croatian legal system is an exception to the fundamental rule contained in the General Administrative Procedure Act, which stipulates that a failure to settle an administrative matter is the foundation for protecting a party's rights by filing an appeal in an administrative procedure or by initiating an administrative dispute. ${ }^{25}$ Therefore, in order for a

22 Article 25, paragraphs 1 through 4 and 6 of the Law on Associations

23 See General Administrative Procedure Act, Official Gazette, no. 47/2009

24 Article 25, paragraph 8 of the Law on Associations

25 Article 12, paragraph 1 and Article 105, paragraph 2 of the General Administrative Procedure Act, and Article 3, paragraph 1, subparagraph 3 of the Law on Administrative Disputes, Official Gazette, no. 20 /2010, 143/2012, 152/2014, 94/2016, and 29/2017 
party to be able to protect its rights and legal interests, in Croatia, it has the opportunity to use appropriate legal remedies.

In Croatia, instances of the statutory presumption of registration generally constitute an exception to the legal regulation. ${ }^{26}$ In principle, the statutory presumption of registration is not inadmissible from the point of view of the legislator; however, it should not be taken as a rule. The General Administrative Procedure Act identifies such a possibility in a particular administrative area, but, at the same time it ties it to a more cumulatively fulfilled assumption. This Act prescribes that a party's request shall be deemed to have been approved if a public law authority, in a procedure initiated at the orderly request of the party in which it is authorized to directly resolve an administrative matter, fails to issue a decision within the prescribed time limit, but only if so explicitly prescribed by law which regulates an individual administrative area. In such a case, the party shall have the right to request that the public law authority issue a decision establishing that the party's request has been accepted, and the public law authority shall issue such a decision within eight days of the party's request. ${ }^{27}$

Affirmative interpretation of the silence of an administrative body and the socalled statutory presumption of registration are not accepted as a general rule in any Member State of the European Union or in the practice of the bodies of this supranational organization. In Italy, for example, in administrative proceedings, there is a wide range of options for approving a party's request, but with a number of protective and safeguarding measures against possible misuse and jeopardy to the public interest in such cases. Therefore, in practice, it is more often a negative statutory presumption, i.e., a statutory presumption that, in the event of a failure of the body to resolve the administrative matter within the prescribed time limit, the party's request is rejected rather than accepted. Most often, as in Croatia, it is prescribed that this constitutes a reason to use legal remedies for the purpose of protecting the party's rights from the untimely resolution of the governing body and does not relate to either a positive or negative statutory presumption. The legal

26 Article 102 of the General Administrative Procedure Act. Positive presumption in the Croatian legal system can be found in Article 142, paragraph 6 of the Nature Protection Act, Official Gazette no. 80/2013, 15/2018, 14/2019, and 127/2019, Article 42, paragraph 4 and Article 45, paragraph 3 of the Healthcare Act, Official Gazette no. 100/2018 and 125/2019, Article 178, paragraph 2 of the Labour Act, Official Gazette, no. 93/2014, 127/2017 and 98/2019, etc. See also Directive 2006/123/EC of the European Parliament and of the Council on services in the internal market (2006) OJ L376 / 36 68

27 See Judgment of the High Administrative Court of the Republic of Croatia, file no. Usž-2162/15-2, of 9 December 2015, Judgment of the Administrative Court in Split, file no. 3 UsI-378/15-7, of February 22, 2017 and Judgment of the Administrative Court in Rijeka, file no. 4 UsI-1514/14-7, of October 24, 2016 
doctrine emphasizes that the system of negative motives, i.e., the motives for rejecting a party's claim, is a "more cautious approach" that manages to reconcile the two conflicting requirements of the rule of law: the protection of the individual and the protection of the objective legal order and public interest. The aspiration of the system of positive statutory presumption is to discipline the administrative bodies, to contribute to the cost-effectiveness and efficiency of the procedure, and to relieve second-instance bodies and administrative courts of additional work. However, positive cases may sometimes violate the fundamental principles of procedural law, legal certainty, and equality of individuals before the law. ${ }^{28}$

The statutory presumption of registration regarding the association registration in the Registry Bookof the Croatian legal system has existed for years. The same statutory presumption was prescribed by the Associations Act of 1997, as well as the Associations Act of 2001. ${ }^{29}$ The legislator thereby seeks to strengthen the party's position in the conduct of administrative proceedings, ${ }^{30}$ whereby the process of acquiring the legal personality of associations in Croatia has been simplified and accelerated. This provision certainly contributes to the implementation of the principle of the efficiency of the administrative procedure, as well as the proportionality in the protection of the parties' rights. ${ }^{31}$ Such an approach by the legislator can be very useful in the process of registering a number of associations active in the fields of culture, sports, or environmental protection, as it relieves the officials from making decisions in writing, thus saving public administration's working and time resources. However, such an approach may also generate difficulties that arise from commitments made by associations, whose organization and operation are not aligned with applicable regulations of the Republic of Croatia.

The statutory presumption of registration for the association registration in the Registry Book is not constitutionally disputed, but what can be challenged is the objective which such a formulated provision achieves. The Constitutional Court of the Republic of Croatia has already questioned the constitutionality of this provision and found no reason to repeal it. ${ }^{32}$ It is undisputed that this type of legal

28 See more on this in Šikić, M., Pravna zaštita od šutnje uprave prema novom Zakonu o općem upravnom postupku, Novi Zakon o općem upravnom postupku i modernizacija hrvatske uprave, Institute of Public Administration, Zagreb, 2009, pp. 198-201 and Šikić, M., Pravna zaštita od nerješavanje upravne stvari u hrvatskom i poredbenom pravu, doctoral dissertation, Zagreb, 2008, p. 157

29 Article 18, paragraph 1 of the Law on Associations, Offizial Gazette, no. 70/1997 and Article 17, paragraph 1 of the Law on Associations, Official Gazette, no. 88/2001

30 Ljubanović, B., Novi Zakon o općem upravnom postupku i posebni upravni postupci, Hrvatska javna uprava, vol. 10, no. 2, 2010, pp. 321-322

31 Articles 6 and 10 of the General Administrative Procedure Act

32 See Decision and Ruling of the Constitutional Court of the Republic of Croatia no. U-I-884/1997, U-I-920/1997, U-I-929/1997, U-I-956/1997, U-I-453/1998, U-I-149/1999 
regulation is harmonized with the general administrative procedural law in the Republic of Croatia, i.e., the General Administrative Procedure Act. However, the question arises whether its application may in some cases result in the registration in the Registry Book of those associations established with the aim of promoting unconstitutional values in the Republic of Croatia or of organizations which do not meet the legal requirements for acquiring legal personality, solely due to the inefficient functioning of the competent authorities. It should not be forgotten that the right exercised on the basis of the statutory presumption of registration cannot be challenged with the legal remedies for substantive purposes, but can only be challenged for formal reasons. In the Croatian administrative practice, it is not uncommon to encounter efforts to registry in the Registry Book those associations whose activities are contrary to the positive legal regulations on the organization and activity of associations. ${ }^{33}$ Therefore, the question arises whether such regulation of the association registration in the Registry Book has adequately ensured the implementation of the Law on Associations, as well as other laws governing the areas in which the associations operate.

\section{LEGAL REGULATION OF ASSOCIATION REGISTRATION IN COMPARATIVE LAW}

Since it is, in principle, allowed in administrative law to depart from the rules of general administrative procedural law in certain administrative areas, it is interesting to consider whether, in comparative law, it is also common to prescribe the statutory presumption of registration in case of failure of the competent authority to decide on the association registration in the Register. Particular consideration is given to the laws of Germany, France, and Italy, as states whose legal systems strongly influence the development of Croatian administrative law in the normative sense, but also the law of Slovenia and Serbia, as neighbouring countries, with which Croatia shared the same legal order for 45 years.

International documents, such as the European Convention for the Protection of Human Rights and Fundamental Freedoms and the Charter of Fundamental Rights of the European Union, give States broad liberties to regulate the freedom of association. They do not impose any rules or restrictions on the exercise of oversight over the establishment and operation of the associations themselves, leaving these issues within the exclusive competence of each individual state. Therefore, the states differently regulate the control that is carried out at the moment of the

33 See Judgment of the Administrative Court of the Republic of Croatia, no. Us-9296/2005-4, of October 14, 2009 and Judgment of the Administrative Court in Rijeka, no. 2 UsI-1371 / 14-12, of April 07,2016 
association registration, and with which the acquisition of legal personality of the association is regularly linked, as well as the subsequent supervision of the work and activities of the association.

In German law, as in Croatian law, there are associations with legal personality and those with no such personality. In order for an association to acquire legal personality, it must be registered in the Registry Book of Associations kept with the Municipal Court (Ger. Amtsgericht) based on the seat of the association. For the purpose of founding the association, the Assembly of the association is obliged to appoint the board of directors (Ger. Vorstand), ${ }^{34}$ which is responsible for submitting all documents passed in the process of founding the association to the notary public. It is the task of the notary public to verify whether the documents required for the establishment of the association comply with the law. ${ }^{35}$ Subsequently, the board of directors submits to the Court a request for the association to be registered. The Court specifically assesses the objective of establishing the association, which should not be directed to the pursuit of any commercial activity. ${ }^{36}$ In case the prerequisites for establishing the association have been fulfilled, the Court shall enter the association in the Registry Book of Associations. If the prerequisites have not been met, the Court rejects the application for association registration, and the applicants have the right to challenge the appeal before the hierarchically higher court. Thus, in Germany, at the very foundation of the association, preventive supervision is carried out in two instances: by a notary public, who verifies the correctness of the documents passed at the founding assembly of the association, and then by the Court, which specifically considers the objectives of the association's establishment. ${ }^{37}$ Associations that do not have legal personality are not subject to the registration procedure described here. It can be concluded that the founding of an association, which is a legal person in Germany, is subject to the judicial registration of such an association in the Registry Book of Associations and, in Germany, the statutory presumption of registration does not apply, all with the aim of verifying the prerequisites for the association's establishment and especially its activities prior to the beginning of its activities.

34 Von Hippel, T., Nonprofit Organizations in Germany, in: Hopt, K. J.; Von Hippel, T. (eds.), Comparative Corporate Governance of Non-profit Organizations, Cambridge University Press, 2010, p. 201

35 Lester, S.M., The International Guide to Nonprofit Law, John Wiley \& Sons, Inc., New Jersey, 1997, p. 121.

36 Von Hippel, op. cit. note 34, p. 201

37 Von Hippel, T., Legal Aspects of Civil Society Organizations and Their Relation with Government: Germany, in: Van der Ploeg, T. J.; Van Veen, W.J.M.; Versteegh, C.R.M., (eds.), Civil Society in Europe, Minimum Norms and Optimum Conditions of its Regulation, Cambridge University Press, 2017, p. 385 
The distinction between associations with and without legal personality is also present in French law. Associations with legal personality in that country are further divided into two groups: associations that perform publicly beneficial activities (Fr. association reconnue d'utilité publique) and other associations. Namely, both of these groups of associations have legal personality, but in doing so, associations performing publicly beneficial activities have rights just like any other legal entity. They can own any form of property that serves their purpose, including land and forests. They are authorized to receive donations, regardless of the amount, with the obligation to report such donations to the competent governing body. ${ }^{38}$ It is interesting that these associations have the power to sue in any case relating to the scope of such an association, which is an exception to the rule that no one may bring an action in cases relating to another person, which are generally applicable in France. However, the preconditions for acquiring such special status of these associations are more demanding. In addition to the decision on establishment, which must be published in the official gazette, the statute of such an association must contain specially prescribed provisions. As a rule, associations should have 200 members or more, must carry out an activity designated by law as an activity of particular interest to the state, be financially stable, act as a non-profit, and be independent. Before granting special status to such an association, it should be active for three years in the so-called trial period. ${ }^{39}$ The state exercises significant influence over these associations, so that the President of the association is appointed by the Minister, while the business books, activities, and overall operations of these associations are supervised by the competent governing body. ${ }^{40}$ Whether the association fulfills the special prerequisites for the purpose of recognizing the status of the association performing publicly beneficial activities is decided in the administrative procedure, and a person appointed by the general assembly of the association is authorized to submit the request for recognition of such status. The request is submitted to the Minister of the Interior (Fr. Ministre de l'Intérieur), who may request the opinion of the City Council of the city where the association is based and the opinion of the prefect (Fr. préfet) in connection with the request. The final opinion on eligibility for the special status of such an association is issued by the State Council (Fr. Conseil d'Etat). If this opinion is positive, the acquisition of the special status is decided by a decree signed by the Prime Minister and the Minister of the Interior. ${ }^{41}$ Due to the importance of associations performing pub-

\footnotetext{
38 Deckert, K., Nonprofit Organizations in France, in: Hopt, K. J.; Von Hippel, T. (eds.), Comparative Corporate Governance of Non-profit Organizations, Cambridge University Press, 2010, p. 275

39 Ibid., pp. 277-278.

$40 \quad$ Lester, op. cit. note 35, p. 104

41 Deckert, op. cit. note 38, pp. 278-279
} 
licly beneficial activities in France, the procedure for acquiring the special status of such associations is firmly state-related and no statutory presumptions apply.

In order for an association to acquire legal personality in France, it is sufficient for the founders of the association to submit to the prefect of the department, in which the association has its seat, a statement establishing the association and to have it published in the official gazette. Such a statement should include the statutory elements, i.e., an indication of the name and objectives of the association, the seat of the association and the names, address of residence, and nationality of the persons authorized to manage the association. Apart from these two conditions, no additional formalities are required for an association to acquire legal personality under French law, so whenever the statement contains all the prescribed parts, the competent national authority must not reject it. ${ }^{42}$ Possible violations of the law and other regulations and illegalities in its work may be determined by the Court, but only subsequently, i.e., after the establishment and acquisition of legal personality. The reason for the relatively undemanding procedure for associations to acquire legal personality is reflected in the very limited rights they enjoy, despite their legal personality. Although they have the right to participate in judicial and other legal proceedings, their rights are limited in connection with the receipt of donations and the acquisition of goods. They have the ability to receive donations in goods and services, donations in gifts or inheritance; however, only up to a certain amount of money. They must report these donations to the competent governing body, which may then raise an objection, considering that the association must not benefit from such a donation given the purpose of its establishment. ${ }^{43} \mathrm{In}$ other words, these associations may only own property that serves the purpose of establishing the business. ${ }^{44}$ Consequently, in France, with regards to associations which are legal entities but not established for the purpose of carrying out publicly beneficial activities, greater emphasis is placed on the subsequent supervision of their work than on the preventive supervision of their establishment and registration.

With regards to legal personality, associations also differ in Italian law. It is important to establish an association as a legal entity here as well, because it provides a number of benefits. Such an association can be funded by public law entities, receive donations, acquire real estate, etc. In Italy, an association acquires legal personality in a formal proceeding conducted by a competent authority in the

\footnotetext{
42 Lester, op. cit. note 35, p. 103

43 Deckert, op. cit. note 38, pp. 274-275

44 Lester, op. cit. note 35, p. 101
} 
province or region. ${ }^{45}$ This body shall determine whether the requirements laid down by law for the registration of an association as a legal person have been fulfilled, among which the objective of establishing the association has been specifically considered as well as whether it has sufficient financial resources to achieve this objective. The competent authority shall decide on the application for the association registration in the Registry Book of Associations within 120 days, or, within the same period, inform the applicants of the reasons preventing its registration. If the procedure determines that the requirements for the registration of the association have not been fulfilled, the applicant may supplement the documentation enclosed with the application within 30 days. However, if, within the next 30 days, the competent body does not notify the applicant of the reasons for the rejection, or decides on the registration of the association in the Register, it shall be presumed that the application for association registration in the Registry Book has been rejected. ${ }^{46}$ It is interesting to note that, in Italy, there is a negative statutory presumption in the decision-making process of association registration in the Register. Consequently, if the competent authority does not decide within the prescribed period, it is considered that the application for association registration in the Registry Book has been rejected.

In Slovenia, the association registration is carried out by an administrative body (Slov. enota) competent in the seat of the association. The application for registration must be accompanied by the minutes of the founding assembly, the founding act of the association, the list of founders, and the decision issued by the legal entity's competent body. The seat of the association, information on the person authorized to represent it, and the powers of representation as well as the proposal of the association's activity are indicated. ${ }^{47}$ The competent authority shall decide on the application for registration within 30 days of the receipt of the application. If the request is incomplete or the body determines that the founding act of the institution does not comply with the law, it shall inform the applicant thereof and invite him to modify the deficiencies within a period of not less than 15 days or more than three months. If the applicant fails to modify the identified deficiencies within the given deadline, the application for registration of the association shall be deemed to have been withdrawn. An appeal may be lodged against the

45 See also Vaccario, C.; Barbetta, G.P., Legal Aspects of Civil Society Organizations and Their Relation with Government: Italy, in: Van der Ploeg, T. J.; Van Veen, W.J.M.; Versteegh, C.R.M, (eds.), Civil Society in Europe, Minimum Norms and Optimum Conditions of its Regulation, Cambridge University Press, 2017, pp. 454-455

46 Preite, F. et al., Atti notarili volontaria giurisdizione, Il procedimento, incapaci, scomparsa, assenza e dichiarazione di morte presunta, UTET Giuridicha, Torino, 2012, pp. 299-300

47 Article 18, paragraph 1 of the Slovenian Societies Act, Official Gazette of the Republic of Slovenia, no. $64 / 2011$ 
decision deciding to Registry Book the association with the Ministry responsible for internal affairs. The appeal against the decision on the registration of the association does not delay the registration of the association in the Registry Book of Associations. ${ }^{48}$ It is interesting to note that, in Slovenia, there is no statutory presumption of registration, but rather on the withdrawal of an application for association registration in the event that such an application is irregular, and the applicant does not act upon the request of the competent administrative body within the set time limit.

Finally, in the Republic of Serbia, the Registry Book of Associations is kept by the Business Registers Agency, which also decides on the association registration in the Register. ${ }^{49}$ If in the process of registering an association it is determined that the association is secret or paramilitary, or that the goals and activities of such association pose a violent danger to the constitutional order and violate the territorial integrity of the Republic of Serbia, violate human rights or rights of minorities, or aim to provoke and incite inequality, hatred, and intolerance based on racial, national, religious, or other grounds, as well as on the basis of sex, gender, physical, psychological, or other characteristics and abilities of a person, the conclusion against which no appeal is allowed shall terminate the association registration in the Register. In doing so, the Agency submits to the Constitutional Court a motion to ban such an association. Upon the adoption of the Constitutional Court's decision, and depending on its content, it shall by decision reject the application for the association registration in the Registry Book if the ban on work has been pronounced or it shall proceed with the association registration if the proposal for a ban on activities has been rejected by the Constitutional Court. ${ }^{50}$

Considering the presented comparative regulation of the acquisition of legal personality of associations, it is evident that the association in all observed legislations acquires legal personality in a particular procedure, and most often based on an administrative decision. However, it is certainly worth noting that none of the observed legislations prescribe the statutory presumption of registration to be registered in the relevant Registry Book in case of a lack of resolution within the deadline prescribed by law. Moreover, in such a case, the Italian law even prescribes a negative statutory presumption, i.e., the statutory presumption of registration rejection, whereas Slovenian law, if the applicant fails to act upon the request of the competent authority, prescribes the statutory presumption of re-

\footnotetext{
48 Article 17, paragraphs 1 and 2, and Article 19, paragraphs 1 through 3 and 5 of the Slovenian Company Act

49 Article 26 of the Serbian Law on Associations, Official Gazette of the Republic of Serbia, no. 51/2009, 99/2011 and 44/2018

50 Article 31 of the Serbian Law on Associations
} 
quest withdrawal. It is interesting to note that French law, in a very simple procedure, assigns legal personality to associations, while the recognition of the special status of associations established to carry out publicly beneficial business is strictly controlled by the State.

It is observable from the analyzed comparative experiences that States do not wish to deprive themselves of the possibility of legality control upon the establishment of an association or its acquisition of legal personality. ${ }^{51}$ Preventive control over the activities of the association is an advantage in the context of respect for rights in general. However, the aim of such supervision should not be to prevent the establishment of an association or the acquisition of its legal personality, but to enable the activities of the association to be harmonized with the constitutional values and legal requirements. Moreover, in accordance with the case law of the European Court of Human Rights, a case in which a State prevents an association from harmonizing its activities with legal provisions by refusing it registration, instead of giving it the ability to comply with legal requirements, is contrary to the restrictions necessary in a democratic society. ${ }^{52}$ Croatian law has granted this request by requiring the competent authority to invite the applicant for registration in the Registry Book of Associations to harmonize the statute, or submit evidence, within a period of not less than 15 days, whenever it finds that the statute of the association does not comply with the law or if the request was not accompanied by the evidence required by law. Therefore, it seems that unlike other discussed legislations, Croatian law is largely directed in favorem of the founders of associations in the process of registering them in the Registry Book of Associations and acquiring legal capacity.

\section{CONCLUSION}

In the Republic of Croatia, associations acquire legal personality by means of entry in the Registry Book of Associations and, consequently, all the benefits arising from such registration, including the right of financing by persons of public law, the right to acquire and dispose of real estate, the right to be holders of other rights and obligations, etc. Members of the association independently determine the goals and activities of the association, provided that such goals and activities are not unconstitutional or illegal. In order to ensure compliance with the law relating to the establishment of associations and the determination of their activities,

51 See Judgment United Communist Party of Turkey and others $v$ Turkey (1998) 26 EHRR 121. See also Radin, M., ibid., note 10, pp. 5-6

52 See Judgment Association of Victims of Romanian Judges and others $v$ Romania, no. 47732/06, 22 March 2016 
they are required to be registered in order to acquire legal personality and thus to assume fully the rights and obligations in the community. It is precisely in view of the supervisory nature of the procedure of association registration in the Registry Book of Associations that the issue concerning the legitimacy of prescribing the statutory presumption of registration in the procedure of association registration in the Registry Book of Associations in Croatian law arises if the competent authority does not take a negative decision within the prescribed deadline. Such regulation, which is present in Croatian legislation and aims to accelerate the exercise of the rights of parties in administrative proceedings, directly contradicts the supervisory role of the competent county bodies in assessing whether an association should be entered in the Registry Book of Associations and thus recognize its legal personality.

Preventive control of the association's compliance with the law, much like the goals the association seeks to achieve, is widely accepted in comparative law. However, none of the comparative systems analyzed prescribe the statutory presumption of adopting a request for the association to be registered in the case of silence of the administrative body. Moreover, in the Italian and Slovenian law, there are examples of statutory presumption of rejecting a party's request or request withdrawal if the applicant fails to act upon the request of the competent authority within the time limit set.

This paper seeks to warn that the Law on Associations does not follow the logic of legal standardization in relation to the attainment of the goal and purpose of a particular legal institute, because if the state opts for the implementation of preventive control in allowing associations to participate fully in legal affairs, this aim should be consistently achieved, not limiting the governing bodies to formal restrictions, which result in the substantive rights of the parties. In other words, the competent authority in this case has the right and obligation to conduct the administrative procedure, to establish the facts, to apply the material regulations, and to make an administrative decision, while the timeliness of its decision-making should be guaranteed by other means. On the other hand, in the case of failing to prescribe preventive control in recognition of a legal personality association, a very effective subsequent control should be in place in the state, which would deal not only with the financial but also the substantive activity of the association, with all the powers necessary for the urgent restoration of the legal status. Whatever approach the legislature takes, it is important that it consistently pursues the set goals, with the mandatory observance of the constitutional guarantee of freedom of association, which must be freely implemented in accordance with the Constitution and laws. 


\section{REFERENCES}

\section{BOOKS AND ARTICLES}

1. Barbić, J., Pravo drustava - knjiga druga, Društva kapitala, Organizator, Zagreb, 1999

2. Blažević, R., Upravna znanost, Faculty of Law University of Rijeka, Rijeka, 2007

3. Brnabić, R., Odgovornost za obveze udruga s pravnom osobnošću, Pravo u gospodarstvu, vol. 51, no. 6, 2012, pp. $1514-1540$

4. Deckert, K., Nonprofit Organizations in France, in: Comparative Corporate Governance od Non-profit Organizations, Cambridge University Press, 2010, pp. 265 - 324

5. Koprić, I., Razvoj i problemi agencijskog modela s posebnim osvrtom na nezavisne regulatore, in: Agencije u Hrvatskoj: Regulacija i privatizacija javnih službi na državnoj, lokalnoj i regionalnoj razini, Institute of Public Administration, Zagreb, 2013, pp. 1 - 29

6. Kotlo, R., Pravo na udruživanje, političke partije i nevladine organizacije u savremenom pravnopolitičkom sistemu, uporednom i medunarodnom pravu, University Press, Sarajevo, 2017

7. Lester, S. M., The International Guide to Nonprofit Law, John Wiley \& Sons, Inc., New Jersey, 1997

8. Ljubanović, B., Novi Zakon o općem upravnom postupku i posebni upravni postupci, Hrvatska javna uprava, vol. 10, no. 2, 2010, pp. $319-328$

9. Preite, F. et al., Atti notarili volontaria giurisdizione, Il procedimento, incapaci, scomparsa, assenza e dichiarazione di morte presunta, UTET Giuridicha, Torino, 2012

10. Radin, M., Pravo na slobodu okupljanja i udruživanja u praksi Europskog suda za ljudska prava i Ustavnog suda Republike Hrvatske, Hrvatska pravna revija, vol. 10, no. 10, 2010, pp. 1 - 13

11. Šikić, M., Pravna zaštita od šutnje uprave prema novom Zakonu o općem upravnom postupku, Novi Zakon o opcem upravnom postupku i modernizacija hrvatske uprave, Institute of Public Administration, Zagreb, 2009

12. Šikić, M., Pravna zaštita od nerješavanje upravne stvari u hrvatskom i poredbenom pravu, Zagreb, 2008, doctoral dissertation

13. Trgovac, S., Pravo na slobodu udruživanja u praksi Ustavnog suda Republike Hrvatske, Hrvatska pravna revija, vol.10, no. 6, 2010, pp. 1 - 9

14. Vaccario, C.; Barbetta, G.P., Legal Aspects of Civil Society Organizations and Their Relation with Government: Italy, in: Civil Society in Europe, Minimum Norms and Optimum Conditions of its Regulation, Cambridge University Press, 2017, pp. 445 - 485

15. Von Hippel, T., Legal Aspects of Civil Society Organizations and Their Relation with Government: Germany, in: Civil Society in Europe, Minimum Norms and Optimum Conditions of its Regulation, Cambridge University Press, 2017, pp. 384 - 399

16. Von Hippel, T., Nonprofit Organizations in Germany, in: Comparative Corporate Governance od Non-profit Organizations, Cambridge University Press, 2010, pp. 197 - 227

17. Zlatović, D., Neformalne udruge prema Zakonu o udrugama i Zakonu o obveznim odnosima, Komore i udruge, Lexpera d.o.o.-Ius info, 2019 


\section{LEGAL SOURCES}

1. Charter of Fundamental Rights of the European Union, (2016) OJ C 202/389-405

2. Constitution of the Republic of Croatia, Official Gazette no. 56/1990, 135/1997, 8/1998, $113 / 2000,124 / 2000,28 / 2001,41 / 2001,55 / 2001,76 / 2010,85 / 2010$, and $05 / 2014$

3. Directive 2006/123/EC of the European Parliament and of the Council on services in the internal market (2006) OJ L376/36-68

4. European Convention for the Protection of Human Rights and Fundamental Freedoms, Official Gazette - International agreements, no. 18/1997, 6/1999, 14/2002, 13/2003, 9/2005, $1 / 2006$, and $2 / 2010$

5. General Administrative Procedure Act, Official Gazette, no. 47/2009

6. Healthcare Act, Official Gazette, no. 100/2018 and 125/2019

7. Labour Act, Official Gazette no. 93/2014, 127/2017, and 98/2019

8. Law on Administrative Disputes, Official Gazette, no. 20/2010, 143/2012, 143/2012, $152 / 2014,94 / 2016$ and 29/2017

9. Law on Associations, Official Gazette, no. 70/1997

10. Law on Associations, Official Gazette, no. 88/2001

11. Law on Associations, Official Gazette, no. 74/2014, 70/2017, and 98/2019

12. Law on Associations, Official Gazette of the Republic of Serbia, no. 51/2009, 99/2011, and $44 / 2018$

13. Law on Obligations, Official Gazette, 35/2005, 41/2008, 125/2011, 78/2015, and 29/2018

14. Nature Protection Act, Official Gazette, no. 80/2013, 15/2018, 14/2019, and 127/2019

15. Regulation on the forms and manner of keeping the Registry book of associations and the Registry book of foreign associations in the Republic of Croatia, Official Gazette no. 4/2015 and $14 / 2020$

16. Societies Act, Official Gazette of the Republic of Slovenia, no. 64/2011

\section{CASE LAW}

1. Administrative Court of the Republic of Croatia, file no. Us-9296/2005-4, 14 October 2009.

2. Administrative Court in Rijeka, file no. 2 UsI-1371/14-12, 07 April 2016.

3. Administrative Court in Rijeka, file no. 4 UsI-1514/14-7, 24 October 2016.

4. Administrative Court in Split, file no. 3 UsI-378/15-7, 22 February 2017.

5. Constitutional Court of the Republic of Croatia file no. U-I-884/1997, U-I-920/1997, U-I929/1997, U-I-956/1997, U-I-453/1998, U-I-149/1999, 03 February 2000, Official Gazette, no. 20/2000.

6. European Court of Human Rights, Sidiropoulos v Greece (1999) 27 EHRR 633.

7. European Court of Human Rights, Refah Partisi and others $v$ Turkey (2003) 37 EHRR 1.

8. European Court of Human Rights, United Communist Party of Turkey and others $v$ Turkey (1998) 26 EHRR 121. 
9. European Court of Human Rights, Association of Victims of Romanian Judges and others $v$ Romania, no. 47732/06, 22 March 2016.

10. High Administrative Court of the Republic of Croatia, file no. Usž-2162/15-2, 09 December 2015 . 